\title{
HOUSING PRICE, MORTGAGE INTEREST RATE AND IMMIGRATION
}

\author{
Fennee Chong \\ Office of Research and Innovation \\ Charles Darwin University \\ e-mail:fen.chong@cdu.edu.au
}

\begin{abstract}
Housing price in New Zealand has appreciated substantially after the Global Financial Crisis, resulting in an affordability problem for first home buyers. This paper studies whether changes in immigration activity and mortgage interest rate influence housing price. Empirical findings derived using VECM confirm the impact of immigration and mortgage interest rate on housing property price. Both variables explain 11.4 percent of the variation of Housing Index. An increase of 1 percent in mortgage interest rate would reduce the housing index movement by 1.44 percent whilst a 1 percent increase in immigrants would increase the housing index by 0.30 percent. In addition, about 2 percent of the short-run deviations of housing prices are adjusted towards the long-run equilibrium each month.
\end{abstract}

Keywords: housing price, mortgage interest rate, immigration.

JEL Classification: E52, J11, R31.

Citation: Chong, F. (2020). Housing price, mortgage interest rate and immigration. Real Estate Management and Valuation, 28(3), 36-44.

DOI: https://doi.org/10.1515/remav-2020-0022

\section{Introduction}

Price inflation of the housing property market in New Zealand has challenged both policy makers and investors (Fraser \& McAlevey, 2015; Demographia, 2017). Due to New Zealanders' overwhelming favor of housing property investment over the past decade, housing properties are being overvalued with a house price-to-income multiple equal to 6.63 for the nation and 9.33 for Auckland as of October 2019 (Chaston, 2019). New Zealand's housing price growth has outpaced countries such as Australia, Canada and the OECD (OECD, 2019). Figure 1 below shows New Zealand's Housing price trends.

Reasons behind the rapid increases in property prices are debated by many. In addition to numerous surveys suggesting that New Zealanders are more confident about investing in housing properties than any other financial assets (Braithwaite \& Kemp, 2007; De Bruin \& Flint-Hartle, 2003), commentators from the media had suggested that increases in immigrants in the recent years are the major reason behind this phenomenon. The dynamics of immigration activities in New Zealand are shown in Figure 2.

Mortgage interest rate can have a significant impact on the overall cost of financing purchases of residential properties. Barker (2019) asserts that New Zealand's low mortgage interest rate has contributed to a higher demand and the soaring housing prices. To prevent further deterioration and to stabilize the housing market, the Reserve Bank of New Zealand has adjusted lending policies including raising the borrowing rates to slow down credit growth. For example, in 2014 alone, the Reserve Bank of New Zealand has raised the Official Cash Rate by twenty-five basis points three times (Reserve Bank of New Zealand, 2014). As can be seen in Figure 3, mortgage interest rates are adjusted depending on the level of the economic activities in the country. 


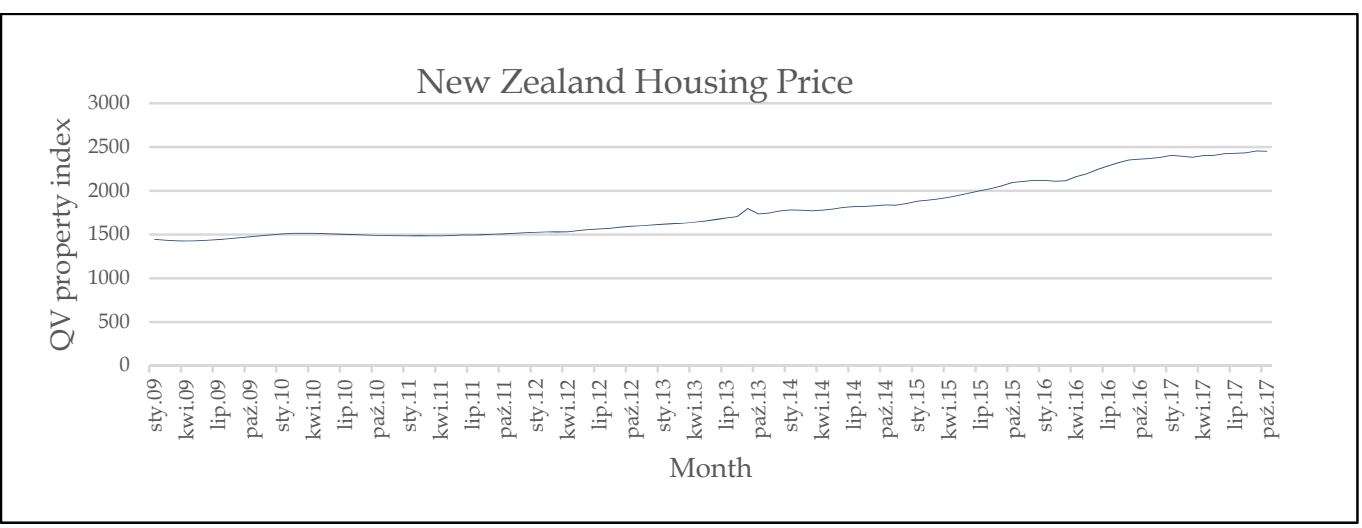

Fig. 1. Housing price trend of New Zealand (January 2009 to October 2017). Source: own study (data from QV Limited).

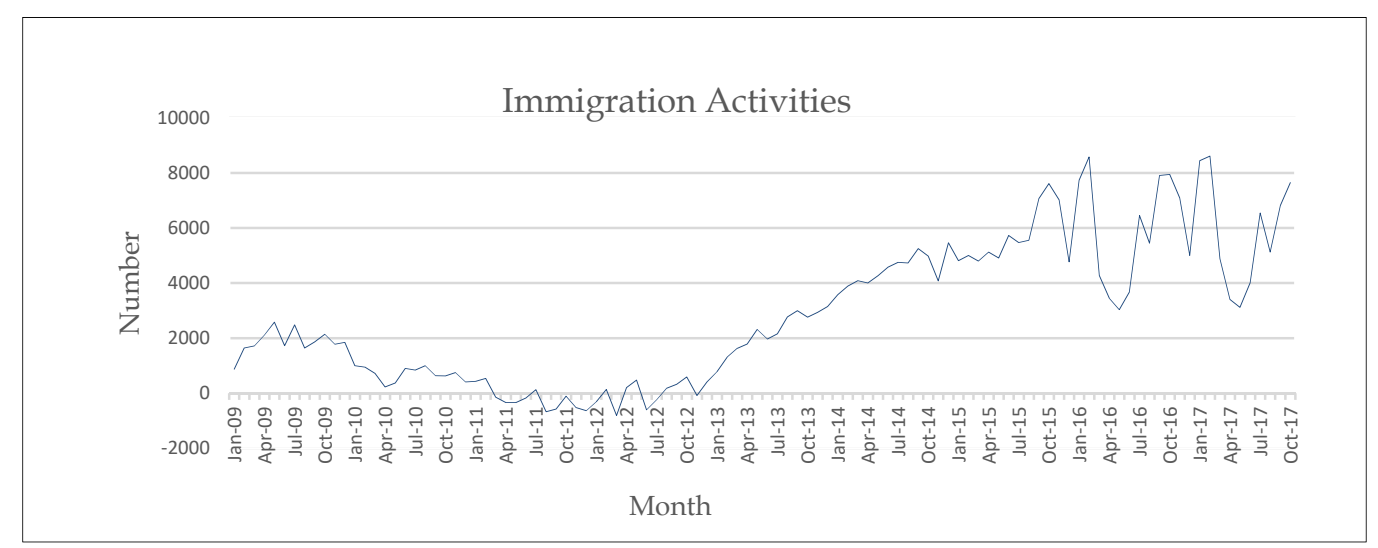

Fig. 2. New Zealand immigration activities. Source: own study (data from Statistics New Zealand).

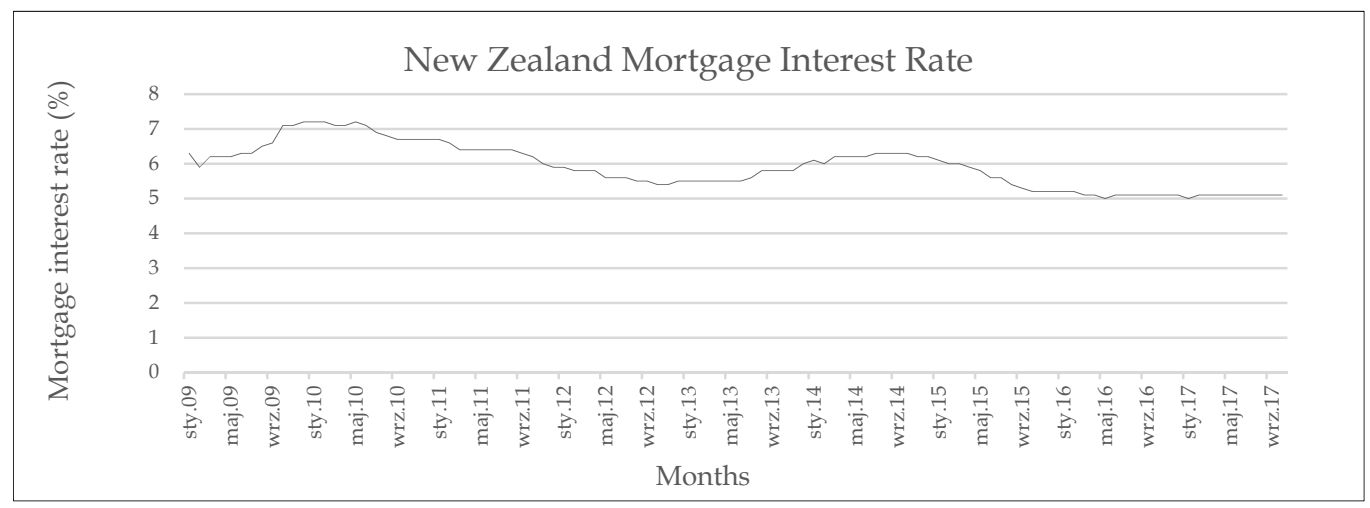

Fig. 3. New Zealand mortgage interest rate. Source: own study (data from Reserve Bank of New Zealand).

Nevertheless, not many researches have attempted to assess whether the changes in mortgage interest rate and demographics connected with immigration have impacted New Zealand's housing price performance after the Global Financial Crisis (GFC). With that in mind, the scope of this paper is to investigate whether immigration is associated with the long-run dynamic of housing price performance and whether intervention on mortgage interest rate is a relevant monetary policy to influence housing prices in New Zealand after the GFC.

\section{Literature review}

Similarly to other assets, housing property performance in New Zealand is affected by demand force. According to Cheung (2011), it is common for rich New Zealanders to own a few properties at the same time. The overwhelming popularity in housing investment in New Zealand in the past decade has led to a persistently large savings-investment imbalance, whereby wealth is concentrated in one 


\section{S sciendo}

asset class, i.e. the housing property. The constant high demand for residential housing has driven the housing market to an unaffordable level in major cities after the Global Financial Crisis. However, this phenomenon has amplified the desire to enter the property market by those who can afford the investment. Consequently, New Zealand's housing index was among the highest on the Asia Pacific list immediately following Hong Kong, and was among the top five most expensive in terms of priceto-rent and price-to-income ratios across the OECD countries (OECD, 2015; Baker, 2019; The Economist, 2017)

Most of the housing property in New Zealand is advertised without a listing price, and final sale price is finalized in the auction. The closest reference that a potential buyer can get is the capital value which is usually stated in the sales brochure. However, Filippova (2014) finds that there is no significant relationship between an upward adjusted capital value and selling price for the Auckland housing sales between Q4 2008 and Q4 2009. Because of the common practice of selling properties via auction, sellers and potential housing buyers tend to anchor and add value on the previous sale price in a similar location as the investor is subjected to recency bias (Tversky \& Kahneman, 1974). The property valuation process is not exempt from the influence of clients and noises (Kucharska-Stasiak et al., 2018). Multi-offers for a house in auctions will inflate and accelerate the prices of housing properties. A study conducted by Shi, Young \& Hargreaves (2010), using data from 1994 to 2004, document the existence of a long run cointegration relationship between trading volume and housing prices in New Zealand, further endorsing the impact of demand on housing price. Studies also indicate that some of the New Zealand residential housing buyers are speculators and are not rational in investment activities (Braithwaite \& Kemp, 2007; Smith \& Searle, 2010; Chong, 2018)

Housing property price is not only affected by the overwhelming demand of residents for their own occupation and speculative purposes (Smith \& Searle, 2010). The influx of immigrants can add further pressure on the demand for housing property. Yu (2006) examines Taiwanese immigrants in Los Angeles stating that well-off immigrants have a significant positive impact on bolstering the demand for residential housing. New Zealand has a proactive immigration policy that encourages the immigration of individuals with desirable skills to the country in order to mitigate the issue of an aging workforce and to enhance national productivity. Larkin at al. (2019), who studied the impact of immigration on housing prices in fourteen countries, postulate a positive relationship between these two variables. An earlier study by Barbu et al. (2017) assesses the correlation between House Price Index and immigration for twenty-one countries for the period of 2007 to 2014, where there is a massive inflation in the housing market. These 21 countries consist of popular immigrant-taking countries in Europe, Asia and New Zealand. They contend that immigration has increased aggregate demand in goods and services, as well as provided labor for 3D - dirty, dangerous and difficult jobs in the host countries. However, immigrants do not acquire a house in the first few years upon arrival.

Nonetheless, similar studies in the New Zealand context have produced different results depending on the sampling period. Coleman and Landon-Lane (2007), when studying the impact of immigration flows on the New Zealand housing prices between 1962 to 2006, contend that a 1\% increase in immigrants led to a $10 \%$ increase in housing prices. A related study conducted by Stillman and Mare (2008), using data for the year of 1996, 1991, 1996, 2001 and 2006 Censuses, and house sales prices from Quotable Value New Zealand, find that migration flows in New Zealand have a significant impact on the fluctuation of housing price whereby a one percent increase in population growth is associated with a $0.2 \%$ to $0.5 \%$ increase in an area's housing price. Nonetheless, they find no association between the growth of foreign-born immigrants and local housing prices. Instead, a strong positive relationship was discovered between inflows of New Zealanders returning from living overseas and the appreciation of local housing price.

In a similar study, Taylor (2014) comments that the increases in immigrants led to an increase in the rental market, as immigrants are having difficulties accessing mortgages due to communication barriers, as well as a lack of credit history and steady income in the host country, such as the USA. Immigrants can be disadvantaged in securing employment due to the lack of a social network and local language skills in the host country, and these factors cause a housing affordability problem (Wang \& Maani, 2014). Carter and Osborne (2009) and Sharma and Murphy (2015 Tversky), who carried out studies on the housing experiences of new immigrants in Winnipeg and Fijian migrants in Auckland, have respectively produced similar findings. Fulanetto and Robstad (2016) investigate the impact of immigration on Norway's housing market and conclude that immigration does not provide any explanation to the rising housing prices. The reason to this is that the immigration influx was 
driven by labor market channel, and new immigrants have no intention to settle in the host country in the long run. Generally, the scale and impact of immigration on housing property prices varies across studies.

Another factor influencing housing property performance is mortgage interest rate. Borio and Lowe (2002) posit that rapid expansion in credit growth and property prices are the leading indicators of financial instability and could trigger a financial crisis. To prevent this from happening, the government could intervene by raising borrowing rates. Monetary policy plays a significant role in determining borrowing rate and, therefore, could influence demand and housing price. According to Waldron and Redmond (2017) mortgage stress causes households to adopt a range of behaviors connected with expenditure, employment, finances and other housing related issues. In the past few years, the Reserve Bank of New Zealand raised the Official Cash Rate numerous times to cool the housing market (Reserve Bank of New Zealand, 2014). This measure was taken with the hope that diminishing profit arising from housing property investment due to a higher mortgage rate would slow down property investment activities and, therefore, promote affordability for first time home buyers.

Indeed, many studies have provided support to the notion that higher mortgage interest rates limit credit growth, and this in turn serves as an important constraint to escalating housing price growth (Bergman, 2015; Nistor \& Reianu, 2018; Tomal, 2019). Belej and Cellmer (2014) assert a significant negative correlation between interest rate and housing prices in Poland, while Xu and Tang (2014) report similar findings on the UK housing market. However, Brissimis and Vlassopoulos (2009) document a contradictory relationship between mortgage interest rate and housing prices for the Greece housing market. Apparently, the relationships between mortgage interest rates and housing price performance are inconclusive and could vary depending on the context of the study.

\section{Methodology: integration, co-integration and causality}

In this study, monthly data from January 2009 until October 2017 is used for the analysis. The performance of housing price was denoted as the Housing Price Index (HPI) and is represented by monthly Housing Price Index for New Zealand obtained from Quotable Value Limited, a state-owned enterprise of the New Zealand government. Since approximately $90 \%$ of the mortgage borrowers opt for the fixed interest rate regime, mortgage interest rate (MIR) is proxied using monthly fixed rate obtained from the Reserve Bank of New Zealand in this study. The number of immigrants (INum) is obtained from Statistics New Zealand. All variables are transformed into logarithm form.

Based on the literature review discussed earlier, the proposed relationship of the variables under study is presented as follows:

\section{Housing Price Index $=f($ Immigrant number, Mortgage interest rate)}

Following similar research (see Shi et al., 2010; Xu \& Tang, 2014) carried out to explore the relationships of these variables, the following econometric tools were adopted: i) Augmented DickeyFuller test to investigate the order of integration for the variables; ii) Johansen and Juselius (1990)'s cointegration test to examine the long-run relationship between the variables; iii) Vector Error Correction model (VECM) to explore the long and short-run dynamics.

\subsection{Description of data}

The monthly movements for all three variables used in this study from January 2009 to October 2017 are depicted in Figure 1, 2 and 3 earlier. Referring to Figure 1, housing prices in New Zealand demonstrate a consistent upward trend during the 106 month study period. On the other hand, immigration activities were rather stable in 2010 and 2011, but increased significantly after 2012. Finally, mortgage interest rate for the study period was at its highest point of approximately $7 \%$ in 2010, and later gradually reduce with another hike in 2014 before stabilizing again at around 5\% for the rest of the study period.

\subsection{Augmented Dickey Fuller}

Before resorting to other analyses, Augmented Dickey-Fuller (ADF) test (Dickey \& Fuller, 1979; 1981) is used to examine the order of the integration of variables. This is a unit root test for stationarity. The 
null hypothesis is: there is a unit root, while the alternate hypothesis is: the time series is stationery (or trend-stationery).

\subsection{Johansen and Juselius (1990)'s cointegration test}

After undertaking the ADF test, if the variables are stationery at first difference and integrated of same order, we proceed to Johansen and Juselius (1990)'s cointegration test to validate the null hypothesis of no cointegration among HPI, INum and MIR, against the alternative hypothesis of cointegration. There are two commonly used tests of cointegration, i.e. the maximum eigenvalue test and the trace test. The two statistics are:

$$
\begin{gathered}
\lambda_{\text {trace }}(r)=-T \sum_{i=r+1}^{n} \ln \left(1-\lambda_{i}\right) \\
\lambda_{\text {max }}(r, r+1)=-T \ln \left(1-\lambda_{r+1}\right)
\end{gathered}
$$

Whereby, $\lambda_{i}$ is the $n-r$ least squared canonical correlations and $T$ is the sample size. The trace test's null hypothesis is that: there are $r$ cointegrating vectors while the alternative hypothesis is that: there are $n$ cointegration vectors. On the other hand, the maximum eigenvalue test's null hypothesis is that: there are $r$ or less cointegrating vectors whilst the alternative hypothesis is: there are $r+1$ cointegrating vectors.

\subsection{Vector Error Correction model (VECM)}

After proving all the variables under study are nonstationary and HPI is cointegrated with MIR and INum, following the Granger representation theorem, this study can continue to explore the relationships of the variables in the model using the vector error-correction mechanism technique. The residuals from the cointegration analysis will be used as the error-correction representation in the following equation:

$$
\Delta Y_{t, i}=\alpha_{i}+\gamma_{i \beta_{i}} Y_{t-1}+\sum_{j=1}^{p} \Gamma_{j, i} \Delta Y_{t-j, i}+\varepsilon_{t, i}
$$

Whereby, $Y_{t, i}=\left(\chi_{i}, v_{j}\right)$ and $\chi_{i}$ is HPI and $v_{j}$ is the vector of INum and MIR. $\alpha$ is a constant vector and the matrix $\Gamma$ reflects the short-run aspects of the relationships for $Y_{t, i}=\left(\chi_{i}, v_{j}\right) . \beta_{i}$ represents the cointegrating vector and $\gamma$ is the error correction coefficient. $\gamma$ is expected to have a negative sign and falls within the range of $-1<\gamma<0 . \gamma$ provides information on the speed of adjustment to the long-run equilibrium.

\section{Empirical Findings}

To investigate the interaction between the housing price index (HPI), immigration number (INum) and mortgage interest rate (MIR), we first performed the Augmented Dickey-Fuller unit root test (ADF) $(1979,1981)$ to identify the non-stationery condition and to detect weather stochastic trend exist in the series. In order to standardize the variables, all the variables are transformed in logarithm format before carrying out the test. In the ADF test, possible deterministic components and lag lengths are taken into consideration. The tests were first conducted in levels and then followed by the first difference for all the series. From Table 1 below, we can see that unit roots are present at the level for all the series, but not in first difference.

Table 1

Augmented Dickey-Fuller unit root test

\begin{tabular}{lcc}
\hline Variables & Log level & Log First Difference \\
\hline Housing Property Index (LHPI) & $2.38(\mathrm{p}=1.00)$ & $9.57(\mathrm{p}=0.0000)^{* *}$ \\
\hline Immigrant Number (LINum) & $-1.02(\mathrm{p}=0.7428)$ & $-10.71(\mathrm{p}=0.0000)^{* *}$ \\
\hline Mortgage Interest Rate (LMIR) & $0.73(\mathrm{p}=0.8340)$ & $10.37(\mathrm{p}=0.0000)^{* *}$ \\
\hline
\end{tabular}

Notes: The reported numbers are the t-statistics. All the variables are transformed into log format. Asterisks $\left({ }^{* *}\right)$ indicate significant at the $5 \%$ level of significance.

The number of lagged level terms was chosen based on the SBC information criteria. These results indicate that there is a possible long-run cointegration relationship and causal relationship (Engle \& 
Granger, 1987). We then proceeded to the multivariate test based on the autoregressive representation of Johansen and Juselius (1990). To gauge the optimum lag length for cointegration analysis, we have used the Final Prediction Error (FPE), Akaike Information Criterion (AIC), Schwarz Information Criterion (SC) and Hannan-Quinn Information Criterian (HQ). Results show that the appropriate lag length is 1 . The results of the multivariate cointegration test are presented in Table 2.

Table 2

Johansen and Juselius Cointegration Test Results

\begin{tabular}{lllll}
\hline $\begin{array}{l}\text { Hypothesised } \\
\text { No. of CE(s) }\end{array}$ & $\begin{array}{l}\text { Max-Eigen } \\
\text { Statistic }\end{array}$ & $\begin{array}{l}\text { Trace } \\
\text { Statistic }\end{array}$ & Critical value (5\%) & \\
\hline & & & Max-Eigen & Trace \\
\hline $\mathrm{r}=0$ & $23.4165^{* *}$ & $30.9741^{* *}$ & 21.1316 & 29.7971 \\
\hline $\mathrm{r} \leq 1$ & 6.4188 & 7.557 & 14.2646 & 15.4847 \\
\hline $\mathrm{r} \geq 2$ & 1.1388 & 1.1388 & 3.8414 & 3.8414 \\
\hline
\end{tabular}

Notes: The Trace test and Max-eigenvalue test indicate one cointegrating equation at the 0.05 level. Asterisks $\left.{ }^{* *}\right)$ denote rejection of the null hypothesis at $5 \%$ level of significance.

The results in Table 2 show that the null hypothesis of zero cointegration $(r=0)$ is rejected by both the Max-Eigen and Trace statistics. This indicates that there exists a single significant cointegrating relationship and there is, therefore, a long-run relationship between HPI and its determinants INum and MIR. After proving the existence of a cointegrating relationship, we move on to examine the interaction among the variables in the model. The result of this empirical analysis has been summarized in Table 3.

Table 3

Summary of VECM results (Johansen Cointegration Equation Estimates)

\begin{tabular}{lll}
\hline Variables & Coefficients & t-statistics \\
\hline constant & 5.431 & \\
\hline LHPI & 1.000 & $-5.250^{* *}$ \\
\hline LINum & 0.301 & $5.394^{* *}$ \\
\hline LMIR & -1.440 &
\end{tabular}

Notes: Asterisks $\left({ }^{* *}\right)$ indicate significant at the $5 \%$ level of significance.

Johansen Cointegration estimates show a significant positive relationship between housing price and immigration activity, with an elasticity of 0.30 . This result is consistent with the earlier findings of Coleman and Landon-Lane (2007) and Stillman and Mare (2008). On the other hand, mortgage interest rate has a significant relationship with housing price and carries the expected negative sign. This implies that investors take the changes of mortgage interest rates into consideration when making investment decisions, whereby a lower interest rate will increase the demand for and price of residential housing, and verse versa.

Table 4

Estimate of Error Correction Model results

\begin{tabular}{lll}
\hline \multicolumn{1}{c}{ Variables } & Coefficients & t-statistics \\
\hline$\Delta$ LHPI $_{\mathrm{t}-1}$ & -0.024 & $-0.246^{*}$ \\
\hline$\Delta$ LHPI $_{\mathrm{t}-2}$ & 0.094 & $0.946^{*}$ \\
\hline$\Delta$ LINum $_{\mathrm{t}-1}$ & -0.004 & $-1.483^{* *}$ \\
\hline$\Delta$ LINum $_{\mathrm{t}-2}$ & -0.003 & $-1.252^{* *}$ \\
\hline$\Delta \mathrm{MIR}_{\mathrm{t}-1}$ & -0.037 & $-0.776^{*}$ \\
\hline$\Delta \mathrm{MIR}_{\mathrm{t}-2}$ & 0.066 & $1.513^{*}$ \\
\hline ECT $(-1)$ & -0.020 & $-2.549^{* *}$ \\
\hline R-squared & 0.114 & \\
\hline
\end{tabular}

Notes: Asterisk $(\mathrm{s})\left({ }^{*}\right)$ and $\left({ }^{* *}\right)$ indicate significant at $10 \%$ and $5 \%$ levels of significance respectively. 
Table 4 presents the results of the error-correction model (ECM). The estimated coefficient of the error-correction term (ECT) has the correct negative sign and is significant at a $5 \%$ level of significance, further reinforcing the fact that the variables in the model are cointegrated. With an $\mathrm{ECT}_{\mathrm{t}-1}$ of -0.02 , implying that about $2 \%$ of the short-run deviations of housing prices would be adjusted towards the long-run equilibrium each month. Results indicate a speedy adjustment to correct any disequilibrium among the variables under study. We have also performed diagnostic tests, with the results indicating the absence of serial correlation and heteroscedasticity. The CUSUM test in Figure 4 also shows that the model is stable within the period of study, whereby the cumulative sum of squared residuals of the estimated housing price index is within the $5 \%$ critical lines.

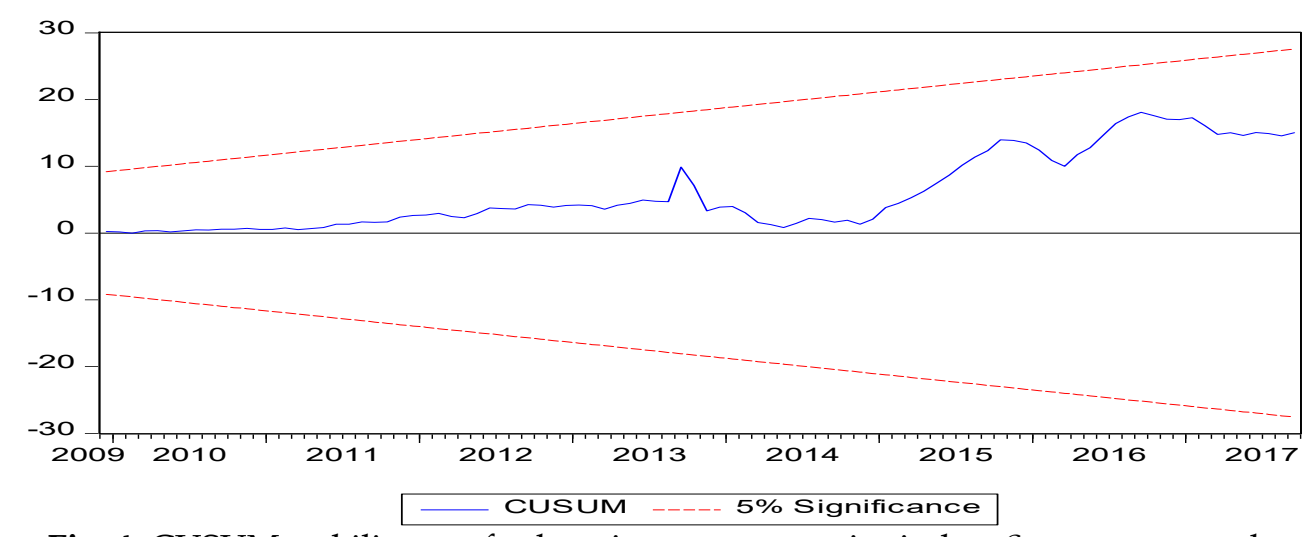

Fig. 4. CUSUM stability test for housing property price index. Source: own study.

\section{Conclusion}

Using monthly data from January 2009 to October 2017, a VECM method was employed to investigate the long-run relationship between mortgage interest rate, immigration activity and the Housing Price Index of New Zealand. Results from the analysis suggest that immigration activity has a positive impact on the housing index. This result is consistent with the findings documented by earlier studies done on the New Zealand housing market (Coleman \& Landon-Lane, 2007; Stillman \& Mare, 2008). Migrating to a new country is challenging; many new migrants are facing severe problems integrating into the new society and obtaining employment to finance the purchase of a house (Barbu et al.,2017; Balampanidis, 2020). As such, most of the immigrants tend to start their new lives in a new country by renting. Economic theory suggests that there is a substitution effect between renting and house ownership and, if this relationship is weak, then the demand for housing becomes more incomeelastic and vice versa. Moreover, an increase in demand would drive up housing prices (Lux, Sunega \& Jakubek, 2020; Tomal, 2019). Results from this study suggest that a 1 percent increase in the number of immigrants is associated with 0.3 percent increase in the Housing Price Index. This relationship is mild but significantly positive. Based on the discussions above, it is apparent that a surge in immigration activity does not exert a massive impact on the housing price in New Zealand, as how fast immigrants manage to integrate into the new society and their level of income could have an impact on the strength of the relationship between immigration activity and housing price as well.

In addition, empirical results from this study have provided evidence supporting the fact that monetary policy remains a valid tool for restraining housing price inflation whereby, an increase of 1 percent in mortgage interest rate would reduce the Housing Price Index movement by 1.44 percent. In fact, numerous studies assert that house owners would generally opt for mortgage conditions that allow lower mortgage repayments (Belej \& Cellmer, 2014; Karpestam \& Johansson, 2019). Higher mortgage interest rates can trigger a range of behaviors and deplete the value of an investment (Waldron \& Redmond, 2017; Tomal, 2019). On the contrary, a reduction in mortgage interest rates would cut the cost of financing and generate a boom in the housing market (Saunders \& Tulip, 2019). Hence, the findings of this study confirm that the mortgage interest rate is an important determinant of demand and, consequently, the housing price in New Zealand. In terms of the speed of adjustment, an estimated coefficient of the $\mathrm{ECT}_{\mathrm{t}-1}$ of -0.02 from this study suggests that about $2 \%$ of the short-run deviations of housing prices would be adjusted towards the long-run equilibrium each month. To conclude, empirical analyses from this study have provided further evidence that mortgage interest 
rate and immigration activity have significant long-run relationship with the Housing Price Index dynamics in New Zealand from 2009 to 2017. It is therefore useful for policy makers, house buyers and property agents to examine the current and future migration and mortgage interest rate policies when scrutinizing and responding to the housing price phenomenon in New Zealand.

\section{References}

Balampanidis, D. (2020). Housing pathways of immigrants in the city of Athens: From homelessness to homeownership. Considering contextual factors and human agency. Housing. Theory and Society, 37(2), 230-250. https:/ / doi.org/10.1080/14036096.2019.1600016

Barker, A. (2019). Improving well-being through better housing policy in New Zealand. OECD Economics Department working no. 1565.

Barbu, T. C., Vuta, M., Strachinaru, A. I., \& Cioaca, S. I. (2017). An assessment of the immigration impact on the international housing price. Amfiteatru Economic, 19(46), 682-689.

Belej, M., \& Cellmer, R. (2014). The effect of macroeconomic factors on changes in real estate prices response and interaction. Oeconomia, 13(2), 5-16.

Bergman, U., Sillemann, B. T., \& Sorensen, P. B. (2015). House prices in Denmark and Sweden. In T. M. Anderson, M. Bergman, \& S. E. H. Jensen (Eds.), Reform capacity and macroeconomic performance in the Nordic Countries. Oxford University Press. https://doi.org/10.1093/acprof:oso/9780198717102.003.0012

Borio, C., \& Lowe, P. (2002). Asset prices, financial and monetary stability: exploring the nexus. Bank for International Settlements, Basel BIS Working Paper No. 40.

Braithwaite, F. D., \& Kemp, S. (2007). Safe as houses: Investor confidence in New Zealand. New Zealand Economic Papers, 41(2), 225-236. https:// doi.org/10.1080/00779950709558510

Brissimis, S. N., \& Vlassopoulos, T. (2009). The interaction between mortgage financing and housing prices in Greece. The Journal of Real Estate Finance and Economics, 39, 146-164. https:// doi.org/10.1007/s11146-008-9109-3

Carter, T. S., \& Osborne, J. (2009). Housing and neighbourhood challenges of refugee resettlement in declining inner-city neighbourhoods: A Winnipeg case study. Journal of Immigrant $\mathcal{E}$ Refugee Studies, 7, 308-327. https:// doi.org/10.1080/15562940903150097

Chong, F. (2018). Does REIT offer a better risk and return contour to the New Zealand residential property investors? Studies in Business and Economic Journal, 13(2), 61-68. https:// doi.org/10.2478/sbe-2018-0020

Coleman, A., \& Landon-Lane, J. (2007). Housing markets and migration in New Zealand - 1962-2006. Reserve Bank of New Zealand Discussion Paper Series DP2007/12.

Cheung, C. (2011). Policies to balance housing markets in New Zealand. OECD Economics Department Working Paper No. 878.

Chaston, D. (2019). Median multiples. http:/ /www.interest.co.nz/property/house-price-income-multiples

de-Bruin, A., \& Flint-Hartle, S. (2003). A bounded rationality framework for property investment behaviour. Journal of Property Investment \& Finance, 21(3), 271-284. https:// doi.org/10.1108/14635780310481685

Demographia. (2017). 13 $3^{\text {th }}$ Annual International Housing Affordability Survey: 2017 Edition, Retrieved from: http://www.demographia.com/dhi12-media.pdf

Dickey, D., \& Fuller, W. (1979). Distribution of the estimators for autoregressive time series with a unit root. Journal of the American Statistical Association, 74, 427-431.

Dickey, D., \& Fuller, W. (1981). Likelihood ratio statistics for autoregressive time series with a unit root. Econometrica, 49(4), 1057-1072. https:// doi.org/10.2307/1912517

Engle, R., \& Granger, C. (1987). Co-integration and error correction: Representation, estimation and testing. Econometrica, 55(2), 251-276. https:// doi.org/10.2307/1913236

Filippova, O. (2014). Do objections to capital value influence house prices? Pacific Rim Property Research Journal, 20(2), 119-128. https:/ / doi.org/10.1080/14445921.2014.11104390

Fraser, P., \& McAlevey, L. (2015). New Zealand regional housing price and macroeconomic shocks. Journal of Property Research, 32(4), 279-300. https:// doi.org/10.1080/09599916.2015.1083606

Furlanetto, F., \& Robstad, Ø. (2016). Immigration and the macroeconomy: Some new empirical evidence. Norges Bank Working Paper 18/2016. 
Johansen, S., \& Juselius, K. (1990). Maximum likelihood estimation and inference on cointegration with applications to demand for money. Oxford Bulletin of Economics and Statistics, 52, 169-210. https://doi.org/10.1111/j.1468-0084.1990.mp52002003.x

Karpestam, P., \& Johansson, S. (2019). Interest-only-mortgages and housing market fluctuations in Denmark. Journal of Housing Economics, 46, 1-24. https:/ / doi.org/10.1016/j.jhe.2019.03.004

Kucharska-Stasiak, E., Zrobek, S., \& Cellmer, R. (2018). Forms and effectiveness of the client's influence on the market value of property - case study. Real Estate Management and Valuation, 26(3), 82-92. https:// doi.org/10.2478/remav-2018-0027

Larkin, M. P., Askarov, Z., Doucouliagos, H., Dubelaar, C., Klona, M., Newton, J., Stanley, T. D., \& Vocino, A. (2019). Do house prices ride the wave of immigration? Journal of Housing Economics, 46, 1-8. https:// doi.org/10.1016/j.jhe.2019.04.002

Lux, M., Sunega, P., \& Jakubek, J. (2020). Impact of weak substitution between owing and renting a dwelling on housing market. Journal of Housing and the Built Environment, 35, 1-25. https://doi.org/10.1007/s10901-019-09661-3

Nistor, A., \& Reianu, D. (2018). Determinants of housing prices: Evidence from Ontario cities, 20012011. International Journal of Housing Markets and Analysis, 11(3), 541-556. https:/ / doi.org/10.1108/IJHMA-08-2017-0078

OECD. (2019). Economic outlook, analysis and forecasts: Focus on house prices. Retrieved from: http://www.oecd.org/eco/outlook/focusonhouseprices.htm

Reserve Bank of New Zealand. (2014, April 24). RBNZ raises OCR to 3.5 percent. Retrieved from: http:/ / www.rbnz.govt.nz/news/2014/04/reserve-bank-raises-ocr-to-3-percent

Saunders, T., \& Tulip, P. (2019). A model of the Australia housing market. Research Discussion Paper RDP 2019-01.

Sharma, R. A., \& Murphy, L. (2015). The housing experiences of Fijian migrants in Auckland. International Journal of Housing Markets and Analysis, 8(3), 396-411. https:// doi.org/10.1108/IJHMA-11-2014-0046

Shi, S., Young, M., \& Hargreaves, B. (2010). House price-volume dynamics: Evidence from 12 cities in New Zealand. Journal of Real Estate Research, 32(1), 75-98.

Smith, S., \& Searle, B. (2010). The Bakewell Companion to the Economics of Housing: The Housing Wealth of Nations. Wiley-Blackwell.

Stillman, S., \& Mare, D. C. (2008). Housing markets and migration: Evidence from New Zealand. Motu Economic and Public Policy Research. Working paper 08/06, 1-45.

Taylor, S. J. (2014). Buying real estate as an immigrant to the US. US News. https://www.money.usnews.com/money/personal-finance/articles/2014/11/04/ buying-realestate-as-an-immigrant-to-the-us

The Economist. (2017). Global house prices. Retrieved from: https://www.economist.com/graphicdetail/2017/03/09/global-house-price

Tomal, M. (2019). The impact of macro factors on apartment prices in Polish counties: A two-stage quantile spatial regression approach. Real Estate Management and Valuation, 27(4), 1-14. https:/ / doi.org/10.2478/remav-2019-0031

Tversky, A., \& Kahneman, D. (1974). Judgment under Uncertainty: Heuristics and Biases. Science, 185(4157), 1124-1131. https:/ / doi.org/10.1126/science.185.4157.1124 PMID:17835457

Waldron, R., \& Redmond, D. (2017). “We're just existing, not living!" Mortgage stress and the concealed costs of coping with crisis. Housing Studies, 32(5), 584-612. https:// doi.org/10.1080/02673037.2016.1224323

Wang, X., \& Maani, S. (2014). Ethnic capital and self-employment: A spatially autoregressive network approach. IZA Journal of Migration, 3(1), 1-24. https://doi.org/10.1186/s40176-014-0018-3

$\mathrm{Xu}, \mathrm{L} .$, \& Tang, B. (2014). On the determinants of UK house prices. International Journal of Economic Research, 5(2), 57-64.

Yu, Z. (2006). A different path to homeownership: The case of Taiwanese immigrants in Los Angeles. Housing Studies, 21(4), 555-579. https:// doi.org/10.1080/02673030600709082 